\title{
Cancer-related thrombotic microangiopathies: case report and narrative review
}

\author{
Micaela La Regina, ${ }^{1}$ Daniele Bertoli, ${ }^{2}$ Tiziana Ciarambino, ${ }^{3}$ Rossella Petacchi, ${ }^{2}$ Ugo Giannoni, ${ }^{4}$ \\ Francesco Orlandini ${ }^{1}$
}

${ }^{1}$ Department of Internal Medicine, Stab. Sant'Andrea, POU del Levante Ligure, ASL5 Liguria, La Spezia; ${ }^{2}$ Department of Clinical and Rehabilitative Cardiology, Stab. San Bartolomeo, POU del Levante Ligure, ASL5 Liguria, Sarzana (SP); ${ }^{3}$ Department of Internal Medicine, Ospedale Villa Malta, Sarno (SA); ${ }^{4}$ Department of Radiology, Stab. San Bartolomeo, POU del Levante Ligure, ASL5 Liguria, Sarzana (SP), Italy

\begin{abstract}
Thrombotic manifestations are common in cancer patients and increase morbidity and mortality. They can affect large or small, venous or arterial vessels. Thrombosis of large arteries and veins is much more studied than that of small vessels. Nevertheless, thrombotic micro-angiopathies - a group of disorders characterized by microvascular thrombosis, thrombocytopenia, and ischemic organ failure - represent a severe and often fatal complication of cancer natural history, as their diagnosis is not always prompt and easy, and treatment controversial or ineffective. Herein, we report a case of sub-acute/acute cor pulmonale in a patient with advanced gastric cancer, treated with mitomycin $\mathrm{C}$, as a good model for differential diagnosis of cancer-related thrombotic micro-angiopathies.
\end{abstract}

\section{Introduction}

The association between thrombosis and malignancy has been recognized, for the first time, in 1865, by professor Trousseau, who drew attention to the high incidence of deep vein thrombosis of the extremities in patients with gastric carcinoma. ${ }^{1}$

Thrombosis represents a major cause of morbidity and mortality in patients with malignancies. It can affect vessels of any type and size: large or small, venous or arterial.

The so-called cancer-associated thrombotic

Correspondence: Micaela La Regina, S.S. Risk Management, SC Governo Clinico, ASL5 Liguria, via B. Fazio 30, 19121 La Spezia, Italy.

Tel.: +39.0187533782.

E-mail: micaela.laregina@as15.liguria.it

Key words: Thrombosis; cancer; thrombotic microangiopathy; pulmonary tumor thrombotic micro-angiopathy.

Conflict of interest: the authors declare no conflict of interest.

Received for publication: 11 July 2018.

Revision received: 24 August 2018

Accepted for publication: 19 September 2018.

This work is licensed under a Creative Commons Attribution NonCommercial 4.0 License (CC BY-NC 4.0).

(C) Copyright M. La Regina et al., 2018

Licensee PAGEPress, Italy

Italian Journal of Medicine 2018; 12:280-284

doi:10.4081/itjm.2018.1065 micro-angiopathies are a heterogeneous, less known group of rare disorders occurring in cancer patients and characterized by a common microscopic lesion (micro-vascular thrombosis, thrombocytopenia and ischemic organ failure), ${ }^{2}$ but different etiopathogenetic mechanisms, clinical features, treatment and prognosis. They include: thrombotic thrombocytopenic purpura (TTP), hemolytic uremic syndrome (HUS), their subsets such as micro-angiopathic hemolytic anemia (MAHA) or transplantation-associated thrombotic micro-angiopathy, and the highly fatal pulmonary tumor thrombotic micro-angiopathy (PTTM). Disseminated intravascular coagulation (DIC), characterized by systemic intravascular activation of coagulation and subsequent depletion of clotting factors and platelets, is not universally accepted among thrombotic microangiopathy (TMA), even if micro-circulation can be involved. ${ }^{3}$

Herein, we report a case of sub-acute/acute cor pulmonale in a patient with advanced gastric cancer, treated by mitomycin $\mathrm{C}$, as a good model for differential diagnosis of cancer-related thrombotic microangiopathies.

\section{Case Report}

A 61-year-old male presented to the Emergency Room (ER) with progressive dyspnea started 3 days before. He was affected by bronchial asthma and systemic arterial hypertension, and two years before, he was diagnosed with gastric cancer with bone and lymph node metastases. After chemotherapy, gastric 
mass had been reduced, but bone metastases had not. So, he had been switched to mitomycin $\mathrm{C}$, some months before. About two weeks before admission, he complained of cough and dyspnea, so he went to his pneumologist who prescribed leukotrienes, steroids, bronchodilators for asthma exacerbation. The patient was also on beta-blockers and ACE-inhibitors.

In ER, he was orthopneic and presented slight legs swelling, reduced lung sounds and bi-basal crepitations, jugular turgescence, fast heart rate without murmurs, blood pressure 150/90 mmhg. Hemogasanalysis showed $\mathrm{pH} 7.54, \mathrm{pO}_{2} 35 \mathrm{mmhg}, \mathrm{pCO}_{2} 19 \mathrm{mmHg}$; chest X-rays, interstitial thickening, small bilateral opacities and left pleural effusion; electrocardiogram (EKG), sinus tachycardia, S1Q3 pattern and negative T V1-4; blood tests, white blood cell count $17,600 / \mathrm{mmc}, \mathrm{N} 83.7 \%$, hemoglobin $15.6 \mathrm{~g} / \mathrm{dL}$, platelets $74,000 / \mathrm{mmc}$, slightly increased troponin I $(0.23 \mathrm{ng} / \mathrm{mL})$, increased natriuretic peptide B $(752$ $\mathrm{pg} / \mathrm{mL})$ and d-dimer $(15,449 \mathrm{ng} / \mathrm{mL})$, normal prothrombin and activated partial thromboplastin time, increased lactate dehydrogenase.

On suspicion of pulmonary embolism (PE), a pulmonary computed tomography (CT) scan was performed. It excluded perfusion defects in main and lobar pulmonary arteries, and showed diffuse groundglass areas, two linear opacities in the lingula and the right inferior lobe.

The patient was admitted to our Cardiology Unit for heart failure. Here, the echocardiogram found pulmonary hypertension with signs of cor pulmonale; in details: enlarged and hypokinetic right ventricle (57 $\mathrm{mm}$ ) with diastolic interventricular septal flattening, enlarged right atrium; dilated pulmonary arteries; moderate tricuspid regurgitation with Vmax $3.75 \mathrm{~m} / \mathrm{s}$. Inferior vena cava diameter was $21 \mathrm{~mm}$ with reduced collapsibility; the estimated pulmonary artery pressure was $75-80 \mathrm{mmHg}$. The left heart and the pericardium were normal. Here, he was started on i.v. methyl-prednisolone $40 \mathrm{mg}$, i.v. furosemide $40 \mathrm{mg}$, oxygen and s.c. fondaparinux $7.5 \mathrm{mg} / \mathrm{die}$. Lower limbs venous ultrasonography excluded thrombosis and perfusion lung scintigraphy documented flow dis-homogeneity, marginal defects and flow anteriorization as for moderate pulmonary hypertension.

A multidisciplinary consultation excluded common micro-angiopathic thrombosis and suspected a PTTM. So, prednisone $100 \mathrm{mg} /$ die and acetylsalicylic acid were added, but he died 2 days after. Family rejected autopsy.

\section{Discussion}

Malignancy-associated thrombosis covers the whole clinical spectrum of venous thromboembolic disease from asymptomatic deep vein thrombosis to fatal PE, including thrombosis in atypical sites and thrombotic micro-angiopathies, ${ }^{4}$ still largely unknown because of their rarity and diagnosis difficulties. Etiopathogenetically, they can be a manifestation of cancer itself, a consequence of chemotherapy or therapy with immunotoxins and antibodies, anti-vascular endothelial growth factor (anti-VEGF) or bone marrow transplantation. The diagnosis is based on the presence of micro-vascular thrombosis, red blood cell destruction, and platelet consumption in patients with active or previous cancer, but no guidelines are available. Recently, a grading of TMA has been proposed by Blake-Haskins et al. ${ }^{5}$ and some authors suggested bone marrow biopsy in patients with apparently primary TMA. ${ }^{6}$

TTP and HUS are the main types, but PTTM is increasingly recognized as a result of a rising cancer incidence and improved diagnostic accuracy.

It was firstly described in 1937 as subacute cor pulmonale, ${ }^{7}$ and re-named PTTM by Von Hervay in $1990 .{ }^{8}$ Pathogenesis is still unclear. It has been hypothesized that embolization of tumoral cells into pulmonary vessels induces endothelial damage and promotes local activation of coagulation and fibrocellular intimal proliferation, causing thrombosis and stenosis of vessels, development of pulmonary hypertension and sometimes micro-angiopathic hemolytic anemia (Figure 1). ${ }^{8}$ Recently, it has been supposed

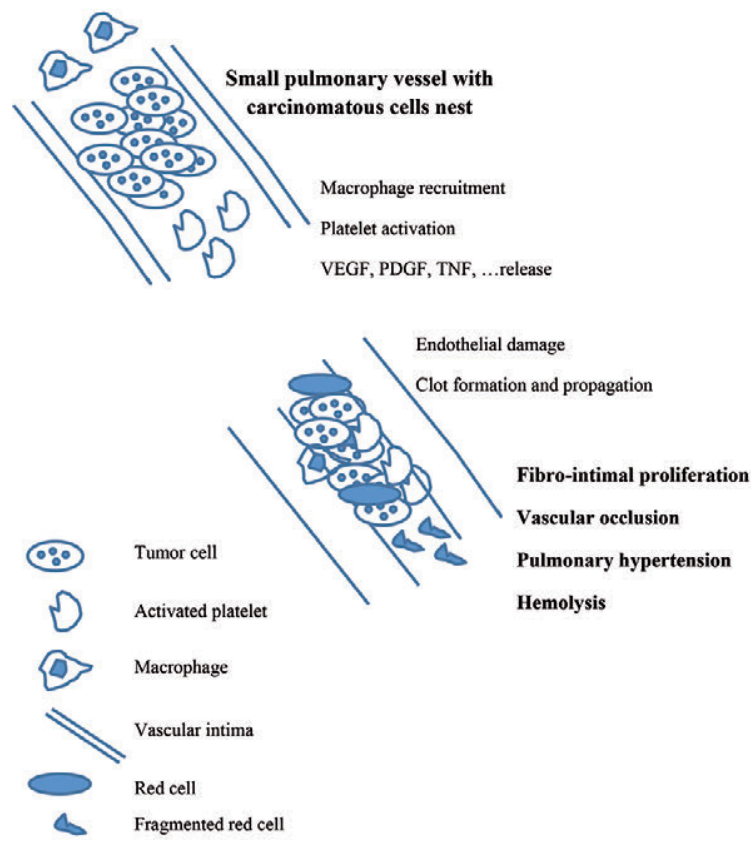

Figure 1. Patho-physiology of pulmonary tumor thrombotic micro-angiopathy. VEGF, vascular endothelial growth factor; PDGF, proliferative agents; TNF, tumor necrosis factor. 
also a role of vascular endothelial growth factor, tissue factor, activated alveolar macrophages and osteopontin.., 10

It is difficult to diagnose and quickly fatal. Only a few cases were diagnosed ante-mortem. ${ }^{11,12}$ Different neoplasms have been described in association with PTTM $^{13}$ but adenocarcinomas prevail. Gastric carcinoma is the most common (up to $60 \%$ of the cases described in the literature), followed by breast, prostate, lung carcinoma, carcinoma of unknown site and hematologic malignancies. It is not known why gastric carcinoma is more frequently associated with PTTM than other cancers and why patients with gastric carcinoma and PTTM are usually younger. Typically, the patient with PTTM complains of acute and progressive dyspnea. Clinical course is much rapid with death occurring within hours or days. Anyway, non-specific symptoms can start from 3 weeks to 6 months before and correlate with high-resolution CT (HRCT) findings. ${ }^{14}$ Chest radiography is normal, or shows diffuse reticulonodular opacities or, less often, Kerley B lines and pleural effusions. Blood tests show raised D-dimer or fibrin degradation products, ${ }^{15}$ and MAHA in some cases. At a later stage, EKG can display RV strains and echocardiography reveals pulmonary hypertension, ${ }^{16}$ but CT pulmonary angiography is usually negative for acute pulmonary embolism..$^{15}$ On HRCT there are diffuse centrilobular nodular opacities (well defined as a result of vascular disease $v s$ blurred ones in bronchiolar disorders) but sometimes they exhibit a tree-in-bud pattern throughout the lung fields like in bronchiolar disease. Other findings are ground-glass opacities due to interstitial or airways edema or inflammation, inter-lobular septal thickening expressing connective tissue, lymphatics and/or pulmonary veins involvement and other signs of acute cor pulmonale. ${ }^{16,17}$ In PTTM, inter-lobular septal thickening is smooth and peripheral in distribution $^{16-18}$ usually without pleural effusions, while in lymphangitis carcinomatosa is more irregular, nodular associated with pleural effusions, and often hilar or mediastinal node enlargement. The distinction between PTTM and lymphangitis carcinomatosa may be difficult and they may coexist. ${ }^{16}$

Diagnosis is really challenging as the clinical deterioration is very rapid: in the literature there are only 11 cases where the diagnosis of PTTM was made whilst the patient was still alive by transbronchial lung biopsy or video-assisted thoracoscopic surgery, CT-guided biopsy, and the finding of tumor cells from wedged pulmonary artery catheter aspiration. This latter has a reported sensitivity of $80-88 \%$ and a specificity of $82-94 \% .{ }^{14,16}$ The use of 2-(F-18)-fluoro-2-deoxy-D-glucose positron emission tomography has been reported in PTTM. ${ }^{15,19-21}$ Anyway, it can be negative because of the small size of lesions or of the histological subtypes of gastric carcinoma. ${ }^{16}$

Treatment is based on reported cases of antemortem diagnosis. A combined approach including chemotherapy, steroids and anti-proliferative agents (anti-PDGF and anti-VEGF) has been used for periods up to 14 months. Anticoagulation and oxygen therapy were also associated. ${ }^{22}$ Dexamethasone $(0.05 \mathrm{mg} / \mathrm{kg}$ daily, in combination with anticoagulants and chemotherapy) resulted in permanent resolution in one case of gastric cancer-associated PTTM, and to rapid improvement in CT changes and clinical symptoms in another with recurrent breast cancer. ${ }^{16}$ Anti-PDGF, imatinib, is a tyrosine-kinase inhibitor and its role in PTTM is supported by immunohistochemical studies. Several reports ${ }^{16,23,24}$ suggested it may prolong survival. Anyway, another anti-PDGF, dasatinib, has been reported to cause pulmonary arterial hypertension..$^{25}$ Anti-VEGF, bevacizumab, has been used alone or in association with imatinib, and it was able to reduce pulmonary hypertension. ${ }^{16}$ Pulmonary vasodilators such as bosentan or ambrisentan have been used in PTTM with conflicting results. ${ }^{23,24}$ Therapeutic thrombolysis has shown no benefit. ${ }^{26}$

In our patient, clinical history (metastatic gastric cancer), clinical presentation (progressive dyspnea) and course (death within 2 days), instrumental examinations (echocardiography, CT pulmonary angiogram and scintigraphy) leave little doubt about the diagnosis of pulmonary tumor thrombotic micro-angiopathy, even if the absence of a histologic confirmation represents a significant limit. Other cancer-related micro-angiopathies, such as TTP, atypical HUS (aHUS) and also DIC, potential differential diagnoses, can be excluded in the absence of hemolytic anemia, neurologic and renal manifestations (TTP and aHUS) and alteration of coagulation tests (DIC). Thrombocytopenia is not a sufficient criterion for diagnosing TTP or DIC. Clues for differential diagnosis and other relevant differences between TMAs are displayed in Tables 1 and 2.

\section{Conclusions}

PTTM is a rare but fatal cancer complication, likely under-diagnosed. It is a micro-angiopathic disorder, characterized by thrombotic occlusion and proliferative stenosis of small pulmonary vessels leading to rapidly progressive pulmonary hypertension, right heart failure and sudden death. Non-invasive, but mainly invasive investigations can help to diagnose disease antemortem. At present, high index of suspicion, early diagnosis and combined therapeutic approach represent the only strategy to improve the outcome. Deep understanding of molecular pathogenesis is needed to identify efficacious targeted therapies. Disease registries and formal trials are desirable to this aim. 
Table 1. Differential diagnosis among cancer-related thrombotic micro-angiopathies.

\begin{tabular}{|c|c|c|c|c|c|}
\hline & DIC & TTP & HUS & TA-TMA & PTTM \\
\hline Clinical presentation & $\begin{array}{l}\text { Ischemia of any organ } \\
\text { or tissue and/or } \\
\text { bleeding }\end{array}$ & $\begin{array}{l}\text { Neurological and } \\
\text { (less) renal } \\
\text { manifestations; } \\
\text { Bleedings }\end{array}$ & $\begin{array}{l}\text { Renal manifestations; } \\
\text { Bleedings; } \\
\text { Diarrhea }\end{array}$ & $\begin{array}{l}\text { Renal, central } \\
\text { nervous system, } \\
\text { gastrointestinal, } \\
\text { pulmonary, cardiac, } \\
\text { endocrine, and } \\
\text { ophthalmic } \\
\text { dysfunction }\end{array}$ & $\begin{array}{l}\text { Cough, progressive } \\
\text { dyspnea, subacute } \\
\text { respiratory failure } \\
\text { with pulmonary } \\
\text { hypertension, } \\
\text { progressive right sided } \\
\text { heart failure, sudden } \\
\text { death }\end{array}$ \\
\hline Coagulation tests & $\begin{array}{l}\text { Altered PT and aPTT; } \\
\text { Hypofibrinogenemia; } \\
\text { Increased D-dimer }\end{array}$ & $\begin{array}{l}\text { Normal PT and aPTT; } \\
\text { Normal/Increased } \\
\text { fibrinogen and } \\
\text { d-dimer }\end{array}$ & $\begin{array}{l}\text { Normal PT and aPTT; } \\
\text { Normal/Increased } \\
\text { d fibrinogen and } \\
\text { d-dimer }\end{array}$ & $\begin{array}{l}\text { Normal PT and } \\
\text { aPTT; } \\
\text { Normal/Increased } \\
\text { fibrinogen and } \\
\text { d-dimer }\end{array}$ & $\begin{array}{l}\text { Normal PT and } \\
\text { aPTT; } \\
\text { Normal fibrinogen; } \\
\text { Increased d-dimer }\end{array}$ \\
\hline Blood count & $\begin{array}{l}\text { Hemolytic anemia; } \\
\text { Schistocytes; } \\
\text { Decreased PLT }\end{array}$ & $\begin{array}{l}\text { Hemolytic anemia; } \\
\text { Schistocytes; } \\
\text { Decreased PLT }\end{array}$ & $\begin{array}{l}\text { Hemolytic anemia; } \\
\text { Schistocytes; } \\
\text { Decreased PLT }\end{array}$ & $\begin{array}{l}\text { Hemolytic anemia; } \\
\text { Schistocytes; } \\
\text { Decreased PLT }\end{array}$ & $\begin{array}{l}\text { Normal or altered } \\
\text { (thrombocytopenia, } \\
\text { hemolytic anemia) }\end{array}$ \\
\hline Other & $\begin{array}{l}\text { Increased LDH; } \\
\text { Reduced haptoglobin; } \\
\text { Negative Coombs test }\end{array}$ & $\begin{array}{l}\text { Increased LDH; } \\
\text { Reduced haptoglobin; } \\
\text { Negative Coombs test; } \\
\text { Increased creatinine } \\
\text { and/or liver enzymes }\end{array}$ & $\begin{array}{l}\text { Increased LDH; } \\
\text { Reduced haptoglobin; } \\
\text { Negative Coombs test; } \\
\text { Increased creatinine }\end{array}$ & $\begin{array}{l}\text { Increased LDH; } \\
\text { Reduced } \\
\text { haptoglobin; } \\
\text { Negative Coombs } \\
\text { test }\end{array}$ & $\begin{array}{l}\text { Normal or increased } \\
\text { LDH, reduced } \\
\text { haptoglobin; } \\
\text { Negative Coombs test }\end{array}$ \\
\hline $\begin{array}{l}\text { Instrumental } \\
\text { examination }\end{array}$ & $\begin{array}{l}\text { Signs of ischemia } \\
\text { and/or bleeding in } \\
\text { involved organs }\end{array}$ & $\begin{array}{l}\text { Signs of ischemia } \\
\text { and/or bleeding in } \\
\text { involved organs }\end{array}$ & Renal ischemia & $\begin{array}{l}\text { Signs of ischemia } \\
\text { and/or bleeding in } \\
\text { involved organs }\end{array}$ & $\begin{array}{l}\text { Echocardiogram: } \\
\text { pulmonary } \\
\text { hypertension and right } \\
\text { heart strain; } \\
\text { Pulmonary } C T \text { : } \\
\text { negative for acute } \\
\text { pulmonary embolism; } \\
\text { nodular or ground glass } \\
\text { lung opacities, signs of } \\
\text { cor pulmonale; } \\
\text { Pulmonary } \\
\text { scintigraphy: } \\
\text { perfusion defects }\end{array}$ \\
\hline Histology & $\begin{array}{l}\text { Fibrin-rich (red) clots, } \\
\text { ischemia and necrosis } \\
\text { in various organs }\end{array}$ & $\begin{array}{l}\text { White clots } \\
\text { (rich-platelet), } \\
\text { ischemia, necrosis }\end{array}$ & $\begin{array}{l}\text { White clots } \\
\text { (rich-platelet), in } \\
\text { microvasculature and } \\
\text { renal arterioles } \\
\text { (typical HUS); } \\
\text { Fibrin-rich (red) clots } \\
\text { with an inflammatory } \\
\text { component and } \\
\text { C5b-9 deposition } \\
\text { (aHUS) }\end{array}$ & $\begin{array}{l}\text { Fibrinoid necrosis } \\
\text { of vessel wall, } \\
\text { arteriolar thrombi } \\
\text { (similar to aHUS) }\end{array}$ & $\begin{array}{l}\text { Diffuse intimal } \\
\text { myofibroblast } \\
\text { proliferation in } \\
\text { pulmonary blood } \\
\text { vessels and multiple } \\
\text { microthrombi }\end{array}$ \\
\hline
\end{tabular}

DIC, disseminated intravascular coagulation; TTP, thrombotic thrombocytopenic purpura; HUS, hemolytic uremic syndrome; TA-TMA, transplant-associated thrombotic microangiopathy; PTTM, pulmonary tumor thrombotic micro-angiopathy; PT, prothrombin time; aPTT, activated partial thromboplastin time; PLT, platelets; LDH, lactate dehydrogenase; CT, computed tomography; aHUS, atypical HUS.

Table 2. Other relevant differences.

\begin{tabular}{|c|c|c|c|c|c|}
\hline & DIC & TTP & HUS & TA-TMA & PTTM \\
\hline Pathogenesis & $\begin{array}{l}\text { Hyper-coagulation and } \\
\text { hyper-fibrinolysis }\end{array}$ & $\begin{array}{l}\text { ADAMTS } 13 \\
\text { deficiency }\end{array}$ & $\begin{array}{l}\text { Endothelial damage } \\
\text { by verotoxin } \\
\text { (typical HUS) } \\
\text { Complement } \\
\text { regulation } \\
\text { deficiency } \\
\text { (atypical HUS) }\end{array}$ & $\begin{array}{l}\text { Multifactorial } \\
\text { etiology of } \\
\text { endothelial } \\
\text { damage }\end{array}$ & $\begin{array}{l}\text { Embolization of } \\
\text { tumoral cells into the } \\
\text { pulmonary vessels } \\
>\text { endothelial damage } \\
>\text { local activation of } \\
\text { coagulation and } \\
\text { fibrocellular intimal } \\
\text { proliferation }\end{array}$ \\
\hline Treatment & $\begin{array}{l}\text { Treatment of underlying } \\
\text { disease; } \\
\text { Platelets, fresh frozen } \\
\text { plasma, if bleeding; } \\
\text { Heparin, if extensive } \\
\text { fibrin deposition }\end{array}$ & $\begin{array}{l}\text { Plasma exchange; } \\
\text { poorly effective; } \\
\text { Treatment of } \\
\text { underlying disease }\end{array}$ & $\begin{array}{l}\text { Plasma exchange; } \\
\text { poorly effective; } \\
\text { Treatment of } \\
\text { underlying disease; } \\
\text { Supportive therapy }\end{array}$ & $\begin{array}{l}\text { Withdrawal of } \\
\text { calcineurin } \\
\text { inhibitors; } \\
\text { Plasma exchange; } \\
\text { Rituximab; } \\
\text { Defibrotide; } \\
\text { Vincristine; } \\
\text { Eculizumab; } \\
\text { Pravastatin }\end{array}$ & $\begin{array}{l}\text { Steroids, ASA, } \\
\text { anticoagulants, } \\
\text { antineoplastic drugs; } \\
\text { Imatinib; } \\
\text { Sildenafil }\end{array}$ \\
\hline Prognosis & $\begin{array}{l}\text { Increases mortality of } \\
\text { underlying condition } \\
\text { by a factor of } 1.5-2\end{array}$ & $90 \%$ mortality & $90 \%$ mortality & $60-90 \%$ mortality & $>95 \%$ mortality \\
\hline
\end{tabular}

DIC, disseminated intravascular coagulation; TTP, thrombotic thrombocytopenic purpura; HUS, hemolytic uremic syndrome; TA-TMA, transplant-associated thrombotic microangiopathy; PTTM, pulmonary tumor thrombotic micro-angiopathy; ASA, acetylsalicylic acid. 


\section{References}

1. Trousseau A. Phlegmasia alba dolens. Lecture on clinical medicine, delivered at the Hotel-Dieu, Paris. London: New Sydenham Society; 1872. pp 281-295.

2. Govind Babu K, Bhat GR. Cancer-associated thrombotic microangiopathies. Ecancer Med Sci 2016;10:649.

3. Levi M. Pathogenesis and diagnosis of disseminated intravascular coagulation. Int J Lab Hematol 2018;40:15-20.

4. Green D, Kwaan HC. Coagulation in cancer. New York: Springer-Verlag; 2009.

5. Blake-Haskins JA, Lechleider RJ, Kreitman RJ. Thrombotic microangiopathy with targeted cancer agents. Clin Cancer Res 2011;17:5858-66.

6. Elliott MA, Letendre L, Gastineau DA, et al. Cancer-associated microangiopathic hemolytic anemia with thrombocytopenia: an important diagnostic consideration. Eur J Haematol 2010;85:43-50.

7. Brill IC, Robertson TD. Subacute cor pulmonale. Arch Intern Med 1937;60:1043-57.

8. Von Hervay A, Illes A, Waldherr R, et al. Pulmonary tumor thrombotic microangiopathy with pulmonary hypertension. Cancer 1990;66:587-92.

9. Chinen K, Kazumoto T, Ohkura Y, et al. Pulmonary tumor thrombotic microangiopathy caused by gastric carcinoma expressing vascular endothelial growth factor and tissue factor. Pathol Int 2005;55:27-31.

10. Takahashi F, Kumasaka T, Nagaoka T, et al. Osteopontin expression in pulmonary tumor thrombotic microangiopathy caused by gastric carcinoma. Pathol Int 2009; 59:752-6.

11. Kayatani H, Matsuo K, Uveda Y, et al. Pulmonary tumor thrombotic microangiopathy diagnosed antemorten and treated with combination chemotherapy. Intern Med 2009;51:2567-70.

12. Miyano S, Izumi S, Takeda Y, et al. Pulmonary tumor thrombotic microangiopathy. J Clin Oncol 2005;25:597-9.

13. Ho A, Szulakowsi P, Mohamid W. The diagnostic challenge of pulmonary tumor thrombotic microangiopathy as a presentation for metastatic gastric cancer: a case report and review of the literature. BMC Cancer 2015; $15: 450$.

14. Godbole R, Ghatol A, Betancourt J, et al. Pulmonary tumor thrombotic microangiopathy: clinical, radiologic, and histologic correlation. J Clin Imaging Sci 2015;5:44.
15. Uruga H, Fujii T, Kurosaki A, et al. Pulmonary tumor thrombotic microangiopathy: a clinical analysis of 30 autopsy cases. Intern Med 2013;52:1317-23.

16. Price LC, Wells AU, Wort SJ. Pulmonary tumor thrombotic microangiopathy. Curr Opin Pulm Med 2016; 22:421-8.

17. Tashima Y, Abe K, Matsuo Y, et al. Pulmonary tumor thrombotic microangiopathy: FDG-PET/CT findings. Clin Nucl Med 2009;34:175-7.

18. Guimarães MD, Almeida MFA, Brelinger A, et al. Diffuse bronchiolitis pattern on a computed tomography scan as a presentation of pulmonary tumor thrombotic microangiopathy: a case report. J Med Case Rep 2011; 5:575.

19. Kane RD, Hawkins HK, Miller JA, Noce PS. Microscopic pulmonary tumor emboli associated with dyspnea. Cancer 1975;36:1473-82.

20. Stahl A, Ott K, Weber WA, et al. FDG PET imaging of locally advanced gastric carcinomas: correlation with endoscopic and histopathological findings. Eur J Nucl Med Mol Imaging 2003;30:288-95.

21. Tashima Y, Abe K, Matsuo Y, et al. Pulmonary tumor thrombotic microangiopathy: FDG-PET/CT findings. Clin Nucl Med 2009;34:175-7.

22. Kitamura A, Nishimura N, Jinta T, et al. A case of pulmonary tumor thrombotic microangiopathy diagnosed by transbronchial lung biopsy and treated with chemotherapy and long-term oxygen and anticoagulation therapies. Case Rep Pulmonol 2013;2013:259080.

23. Minatsuki S, Miura I, Yao A, et al. Platelet-derived growth factor receptor tyrosine kinase inhibitor, imatinib, is effective for treating pulmonary hypertension induced by pulmonary tumor thrombotic microangiopathy. Int Heart J 2015;56:245-8.

24. Ogawa A, Yamadori I, Matsubara O, Matsubara H. Pulmonary tumor thrombotic microangiopathy with circulatory failure treated with imatinib. Intern Med 2013; 52:1927-30.

25. Montani D, Bergot E, Gunther S, et al. Pulmonary arterial hypertension in patients treated by dasatinib. Circulation 2012;125:2128-37.

26. Keenan NG, Nicholson AG, Oldershaw PJ. Fatal acute pulmonary hypertension caused by pulmonary tumour thrombotic microangiopathy. Int J Cardiol 2008; 124:e11-3. 